\title{
Morphological feature of brachial artery and its clinical significance
}

\section{AL TALALWAH, W. ${ }^{1 *}$, GETACHEW, $\mathrm{D}^{2}{ }^{2}$ and SOAMES, R. ${ }^{3}$}

\author{
${ }^{1}$ King Abdullah International Medical Research Center, Department of Basic Medical Sciences Hospital, \\ King Saud bin Abdulaziz University for Health - NGHA, 3127 Riyadh, Saudi Arabia \\ ${ }^{2}$ Anatomy Department, College of Medicine and Health Sciences, Hawassa University, 1560 Awassa, Ethiopia \\ ${ }^{3}$ Centre for Anatomy and Human Identification, College of Art, Science and Engineering, University of Dundee, \\ DD1 5EH Dundee, United Kingdom of Great Britain and Northern Ireland \\ ${ }^{*}$ E-mail: altalalwahw@ksau-hs.edu.sa
}

\begin{abstract}
Introduction: The present study is to provide comprehensive data concerning the morphology of brachial artery which has a clinical significance for clinicians, orthopedics, vascular surgeons and anatomists. Materials and Methods: Routine dissections of the right and left upper limb of 34 adult cadavers ( 20 male and 14 female: mean age 78.9 year) were undertaken. It investigates the characteristics of the brachial artery such as the internal diameter, external diameter, wall thickness and distance of bifurcation of brachial artery. Results: The mean of the external and internal diameters of the brachial artery from proximal to distal ranged from 6.87-5.35 mm respectively. The bifurcation of the brachial artery from the head of radius into its terminal branch radial and ulnar artery ranged from 13.49-13.79 mm, while the distance of bifurcation of common interosseous from origin of the ulnar artery ranged from 33.11-33.45 $\mathrm{mm}$. The angle of bifurcation of the radial and ulnar arteries from the brachial artery ranged from $5.79-7.33^{\circ}$ and $18.640-19.36^{\circ}$ respectively. Due to variability of the brachial artery in the upper limb, the surgical and invasive procedures are performed in the region such as artificial arterial-venous fistula become more difficult and may result in iatrogenic injury. Conclusion: Therefore, it is a clinical significant for surgeons to known the variable morphology and course of brachial artery to minimize surgical complication prior to operation.
\end{abstract}

Keywords: brachial artery, ulnar artery, radial artery, common interosseous artery, anterior interosseous artery, posterior interosseous artery.

\section{Introduction}

The brachial artery is the continuation of the axillary artery at the inferior border of teres major. In the upper part of the arm the brachial artery with its associated vein is accompanied by the median and ulnar nerves and the medial cutaneous nerve of the forearm. The brachial artery passes distally and laterally, lying medial to biceps brachii and anterior to coracobrachialis and brachialis. A major branch of the brachial artery is the profunda brachii which passes into and supplies the posterior compartment of arm. The profunda brachii is the main source of arterial blood to the arm. It accompanies the radial nerve through the spiral groove and is accompanied by its associated veins. In addition, to supplying muscles, the profunda brachii gives off nutrient arteries to the humerus and contributes to the anastomoses around both the shoulder and elbow joints. It ends by dividing above the elbow into two branches: the radial collateral artery which anastomoses anterior to the elbow with the radial recurrent artery, and the middle collateral artery which anastomoses posterior to the elbow with the interosseous recurrent artery. An ascending deltoid branch from the profunda brachii anastomoses with the posterior circumflex humeral artery, a branch of the axillary artery. The profunda brachii artery provides a potential alternative route of blood flow from the axillary artery to arteries below the elbow. As mentioned above, the brachial artery give off deep branches, but it also gives additional branches in the arm.

These are the superior and inferior ulnar collateral arteries, which anastomose with the ulnar recurrent branches of the ulnar artery to form a network around the elbow joint. As it proceeds distally in the arm the brachial artery passes anterior to the median nerve. In the cubital fossa the brachial artery lies deep to the bicipital aponeurosis, which protects it when taking blood from median cubital vein, which itself lies close to the surface of the skin (STANDRING, 2004).

The diameter of major upper limb arteries gives many clues to the management of clinically related problems of humans. It is important that clinicians and anatomists have an understanding of the thickness, diameter and the variability of the brachial artery in the upper limb. As the variability of the brachial artery presents, the possibility of frequently vascular injury has to be considered during a number of surgical and invasive procedures (MALCIC-GÜRBÜZ, GURUNLUOGL, OZDOGMUS et al., 2002). The brachial artery is used to measure the blood. Further, the brachial artery pulse is palpable on the anterior aspect of the elbow region in the cubital fossa. In the cubital fossa, the two branches of the brachial artery, superior and inferior ulnar collateral arteries, which arise proximal to the elbow, anastomose with the ulnar recurrent branches of the ulnar artery distal to the elbow joint. The profunda brachii artery gives rise to a radial collateral artery which anastomoses with the radial recurrent artery while the 
middle collateral artery anastomoses with the interosseous recurrent artery (STANDRING, 2004).

\section{Materials and Methods}

Present study includes dissected of 34 cadavers ( 14 female and 20 male) which is in total 68 upper limbs (34 rights, 34 left) age range 37-96 years in which the brachial artery and its branches were exposed. It targets the bifurcation level of the brachial artery (Figure 1) and its internal and external diameters by using vernier calliper, ruler and a protractor. For the brachial artery, measurements was taken at its proximal origin (lower border of teres major), just below profunda brachii branch, and distal part just proximal to the bifurcation in cubital fossa. Entire measurements were repeated three times and the average calculated. Prior to the measurement programme the upper limb was carefully dissected to expose the muscles in the area, especially teres major to locate the proximal part of brachial artery where the initial measurements of external and internal diameter were taken. The dissection continued down below the profunda brachii artery again to expose the middle of the brachial artery where the second set of measurements of external and internal diameter was taken. Further dissection was conducted around the cubital fossa to enable determination of the level of bifurcation of the brachial artery into its terminal branches where the third set of measurements of external and internal diameter were taken. In the cubital fossa the internal and external diameters of the brachial artery were determined at the bifurcation (Figure 2). The level of bifurcation of brachial artery was also determined with respect to the head of radius (Figure 3 ). The materials used in the measurement programme includes vernier calliper to measure the internal and external diameter (Figure 2) and ruler to measure the position of the bifurcation of the brachial artery (Figure 3).

\section{Result}

The 68 limbs studied all had a brachial artery with anastomosing with branches of other arteries in the region. All brachial arteries were in the expected anatomical position. The data were collected and calculated to measure the mean and standard deviation. T-tests were performed to assess differences in arterial diameter between females and males and right and left sides, as well as along the length of brachial artery. The data were collected from both limbs of 34 cadavers ( 14 female and 20 male): the mean male and female ages were $81 \pm 7.2$ and $75.9 \pm 16.3$ respectively. The combined mean age is 78.9 with standard deviation of 11.9 years. The range of ages of all cadavers was 37 to 96 years (Table 1 ).

Further, the internal and external diameters as well as the thickness of the brachial artery in its proximal, middle and distal parts for both females and males have been measured. In both sexes there is gradual change of size in both internal and external diameter, with the proximal part being larger, decreasing in size in the middle part and becoming larger again in the distal part. The brachial artery was significantly larger in males than females. In addition, the left side thickness of the middle part is significantly $(\mathrm{P}<0.05)$ larger than the right in females (Table 2).

Moreover, the mean, standard deviation and the range of values of the level of bifurcation of the brachial artery with

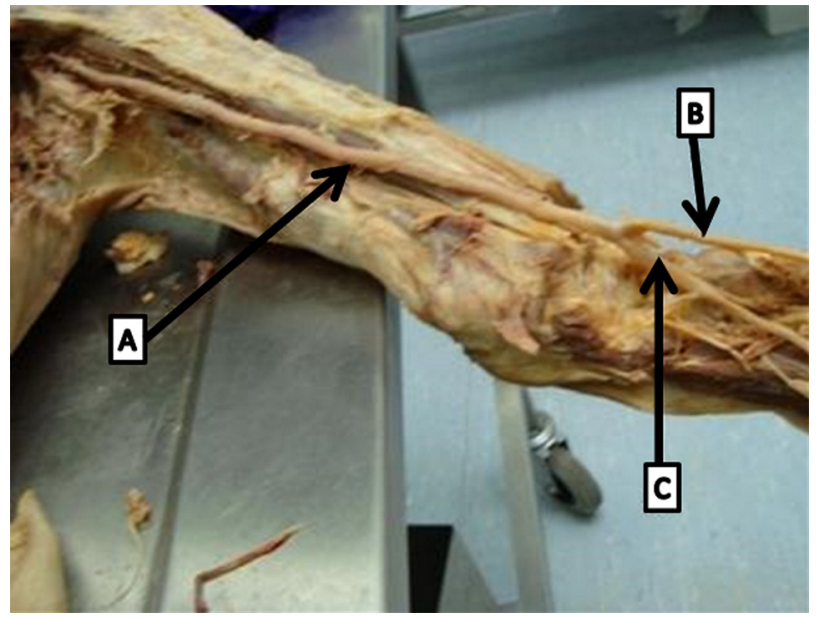

Figure 1. Schematic diagram showing brachial artery (A) radial artery (B) ulnar artery $(\mathrm{C})$.

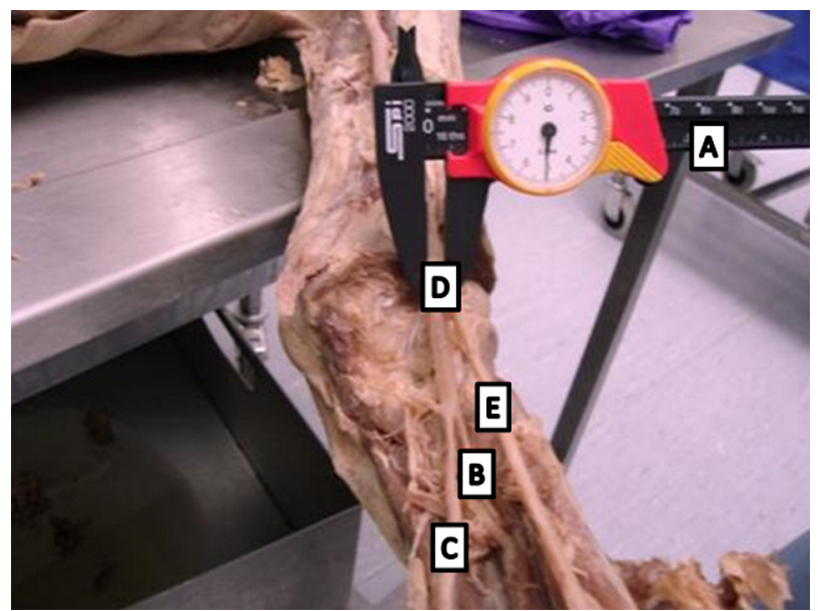

Figure 2. Diagram showing how measurements of the external diameter of the brachial artery at the level of bifurcation were taken. (A) Vernier calipier, (B) Common interosseous, (C) Ulnar artery, (D) Brachial artery, (E) Radial artery.

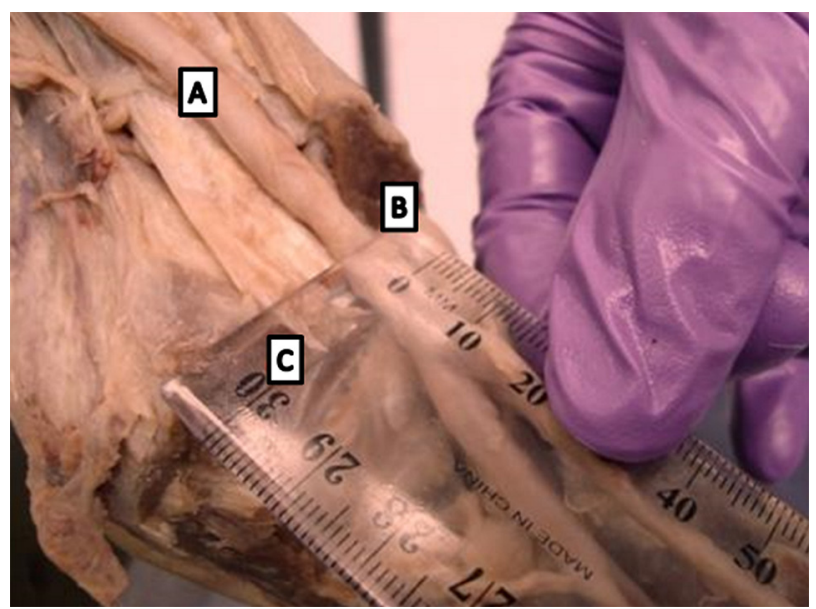

Figure 3. Schematic diagram showing measurement of the distance from the head of the radius to the bifurcation of the brachial artery. (A) Brachial artery, (B) Head of radius, (C) Ruler. 
respect to the superior margin of the head of the radius have been calculated. As can be seen the male value is significantly $(\mathrm{P}<0.05)$ larger than the female value. Negative values indicate that the level of bifurcation is proximal to the superior margin of the head of the radius: this was observed in only one cadaver (Table 3).

\section{Discussion}

The main vascular variability of upper limb occurred in origin, branch and course reported in series studies (MCCORMACK, CAULDWELL and ANSON, 1953; BERGMAN, THOMPSON and AFIFI, 1985; WATANABE, TAKATSUJI, SAKAMOTO et al., 1985; RODRIGUEZNIEDENFUHR, VAZQUEZ, NEARN et al., 2001) ranging from 9\% to $18.5 \%$ (CIERVO, KAHN, PANGILINAN et al., 2001). Recently, it has been recorded to be high privilege as $34.7 \%$ (VANDANA, SURESH and PRABHA et al., 2012). The vascular variability of upper limb is due to either growth or involution of vascular plexus of the limb buds during

Table 1. Number of male and female cadavers, together with the mean, associated standard deviation and age range of each group.

\begin{tabular}{ccccc}
\hline Sample & Number & Mean & SD & Range \\
\hline MALE & 20 & 81 & 7.2 & $66-93$ \\
FEMALE & 14 & 75.9 & 16.3 & $37-96$ \\
Combined & 34 & 78.88 & 11.9 & $37-96$ \\
\hline
\end{tabular}

embryo stage development (SINGER, 1933; MCCORMACK, CAULDWELL and ANSON, 1953; RODRIGUEZ-BAEZA, NEBOT, FERREIRA et al., 1995; JURJUS, CORREA-DEARUAUJO and BOHN, 1999; RODRIGUEZ-NIEDENFUHR, VAZQUEZ, NEARN et al., 2001). The vascular variations of upper limb studies provide several clinical and surgical significances (JURJUS, CORREA-DE-ARUAUJO and BOHN, 1999; PANDEY, GANGOPADHYAY, TRIPATHI et al., 2004).

The brachial artery is a direct continuation of the axillary artery below the teres major (STANDRING, 2004). In few cases, the axillary artery has been reported to terminate into superficial and deep brachial arteries (NAKATANI, TANAKA, MIZUKAMI et al., 1996; CAVDAR, ZEYBEK and BAYRAMICLI, 2000; DURGUN, YÜCEL, KIZILKANAT et al., 2002; YOSHINAGA, TANII and KODAMA, 2003; LAPPAS, LIASKOVITIS and GISAKIS, 2004; CHERUKUPALLI, DWIVEDI and DAYAL, 2008; GOSWAMI, TIGGA and BHARIHOKE, 2013). The superficial bracial artery was previous known as superficial brachioulnoradial artery by Moncayo-Marques in his report in 1941 ranging from 0.14-1.3\% (QUAIN, 1844). In previous report, bifurcation of axillary artery into superficial and deep brachial has been estimated in $13.4 \%$ of Afro-Americans and in $4.6 \%$ of Caucasians (DE GARIS and SWARTLEY, 1928). In current study, the brachial artery is found to be a direct continuation of axillary artery in entire cases.

A congenital absence of the brachial artery has been reported by Ciervo, Kahn, Pangilinan et al. (2001) whereas the brachial artery presence in entire cases in current study. Furthermore, the

Table 2. Means and associated standard deviations $(\mathrm{mm})$ of the external and internal diameters and thickness of the brachial artery proximally, midway along its length and at the level of bifurcation in males and females, as well as for the combined group.

\begin{tabular}{|c|c|c|c|c|}
\hline Sample & Side & & Mean (SD) & \\
\hline \multirow{8}{*}{ MALE } & Left & External diameter & Internal diameter & Thickness \\
\hline & Proximal & $7.24(1.38)^{*}$ & $6.82(1.19)^{*}$ & $0.21(0.38)$ \\
\hline & Middle & $5.34(1.14)^{*}$ & $5.08(0.77)^{*}$ & $0.13(0.18)^{*}$ \\
\hline & Bifurcation & $5.73(1.04)^{*}$ & $5.31(0.73)^{*}$ & $0.21(0.15)$ \\
\hline & Right & External diameter & Internal diameter & Thickness \\
\hline & Proximal & $7.55(1.94)^{*}$ & $7.12(1.89)^{*}$ & $0.21(0.03)$ \\
\hline & Middle & $5.68(1.18)^{*}$ & $5.30(0.80)^{*}$ & $0.19(0.19)^{*}$ \\
\hline & Bifurcation & $5.96(1.02)^{\star}$ & $5.51(0.73)^{*}$ & $0.23(0.15)$ \\
\hline \multirow{8}{*}{ FEMALE } & Left & External diameter & Internal diameter & Thickness \\
\hline & Proximal & $5.77(0.93)$ & $5.17(0.64)$ & $0.30(0.29)$ \\
\hline & Middle & $4.60(0.93)$ & $4.11(0.69)$ & $0.25(0.12)^{\wedge}$ \\
\hline & Bifurcation & $4.81(0.72)$ & $4.39(0.65)$ & $0.21(0.03)$ \\
\hline & Right & External diameter & Internal diameter & Thickness \\
\hline & Proximal & $5.89(1.14)$ & $5.48(1.04)$ & $0.21(0.05)$ \\
\hline & Middle & $4.62(0.95)$ & $4.32(1.00)$ & $0.15(0.06)$ \\
\hline & Bifurcation & $4.93(0.95)$ & $4.49(0.82)$ & $0.22(0.07)$ \\
\hline \multirow{8}{*}{ Combined } & Left & External diameter & Internal diameter & Thickness \\
\hline & Proximal & $6.63(1.41)$ & $6.14(1.29)$ & $0.25(0.34)$ \\
\hline & Middle & $5.04(1.11)$ & $4.68(0.88)$ & $0.18(0.12)$ \\
\hline & Bifurcation & $5.35(1.02)$ & $4.93(0.83)$ & $0.21(0.09)$ \\
\hline & Right & External diameter & Internal diameter & Thickness \\
\hline & Proximal & $6.87(1.83)$ & $6.44(1.78)$ & $0.21(0.03)$ \\
\hline & Middle & $5.24(1.20)$ & $4.90(0.94)$ & $0.17(0.13)$ \\
\hline & Bifurcation & $5.54(1.11)$ & $5.09(0.91)$ & $0.22(0.10)$ \\
\hline
\end{tabular}

*Significantly $(\mathrm{P}<0.05)$ larger than corresponding female value. ${ }^{\wedge}$ Significantly $(\mathrm{P}<0.05)$ larger than corresponding right side value. 
AL TALALWAH, W., GETACHEW, D. and SOAMES, R.

Table 3. Distance $(\mathrm{mm})$ of the level of bifurcation of the brachial artery from the superior margin of the head of the radius.

\begin{tabular}{ccccc}
\hline \multirow{2}{*}{ Sample } & \multirow{2}{*}{ Side } & \multicolumn{3}{c}{ The distance level of bifurcation of the brachial artery from the } \\
& & Mean & SD & Range \\
\cline { 2 - 5 } & Left & 13.9 & 7.68 & $-6.33-30$ \\
\multirow{2}{*}{ Male } & Right & $14.92^{*}$ & 5.18 & $4-25$ \\
& Left & 12.9 & 6.92 & $2.33-25$ \\
\multirow{2}{*}{ Female } & Right & 12.17 & 4.15 & $5-18$ \\
& Left & 13.49 & 7.29 & $-6.33-30$ \\
\multirow{2}{*}{ Combined } & Right & 13.79 & 4.91 & $4-25$ \\
& &
\end{tabular}

${ }^{*}$ Significantly $(\mathrm{P}<0.05)$ larger than corresponding right side value. Negative values indicate that the bifurcation lies proximal to the superior margin.

trifurcation of brachial artery has been reported in series report (PATNAIK, KALSEY and SINGLA, 2001; MALCIC-GÜRBÜZ, GURUNLUOGL, OZDOGMUS et al., 2002; VALLOLA, NAGABHOOSHANA and BHAT, 2008) and estimated in 1.7\% (AL-SOWAYIGH, ZAKI, EL-HAGGAGY, et al., 2013).

In cubital fossa, the brachial artery usually bifurcates into radial and ulnar artery at the level of neck of radius (STANDRING, 2004 ) in $21.7 \%$ while it divides either above in $11.7 \%$ or below it in 6\% (AL-SOWAYIGH, ZAKI, EL-HAGGAGY, et al., 2013). Also, the bifurcation of the brachial artery occurred proximal to interchondyler line referred as a high division in which has been reported in series studies (MOORE and PERSAUD, 1999; CELIK, GÖRMÜS, ALDUR, et al., 2001; PATNAIK, KALSEY and SINGLA, 2001; QUARRAT, KAUSER and RAZA, 2002; CHERUKUPALLI, DWIVEDI and DAYAL, 2008; SATHYNARAYAN, SUNITHA, SHAIK et al., 2010; SINGH, GUPTA, BARGOTRA et al., 2010). The high brachial artery bifurcation is most common vascular variation of the upper limb (MCCORMACK, CAULDWELL and ANSON, 1953; RODRIGUEZ-NIEDENFUHR, VAZQUEZ, NEARN et al., 2001) which occurs in $12.3 \%$ (KIAN, SHAPIRO, SALMAN et al., 2012) or 10\% (AL-SOWAYIGH, ZAKI, EL-HAGGAGY, et al., 2013). In present study, the brachial artery bifurcates into ulnar and radial arteries in different level distal to the superior margin of the head of the radius. In current study, the brachial artery has regular course in 95\% in United Kingdom population whereas it was $91.7 \%$ in Indian population (VANDANA, SURESH, PRABHA et al., 2012). In current study, the bifurcation level occurs distal to the superior margin of the head of the radius more in male than in female. In one male cadaver, the level of bifurcation is proximal to the superior margin of the head of the radius in $5 \%$ and classified as high bifurcation of the brachial artery based on previous reports. Recently, the high brachial bifurcation found to be in $5 \%$ of Indian population (VANDANA, SURESH, PRABHA et al., 2012) whereas it found to be in 3\% of United Kingdom population (Table 3). The high bifurcating level of brachial artery has been accounted be predictor of brachiocephalic fistula failure (LIOUPIS, MISTRY, JUNGHANS et al., 2010; KIRKSEY, 2012).

Based on ultrasound study, the success rate of artificial arteriorvenous fistula for hemodialysis purpose is increased as the internal diameter of artery is more than $0.16 \mathrm{~mm}$ (KIAN, SHAPIRO, SALMAN et al., 2012). Therefore, the main findings of present study are relatively focused on morphology including the external and internal diameter as well as wall thickness of the proximal, middle and distal part of brachial artery. The mean value of combined female and male internal diameter, external diameter and wall thickness of the brachial artery as follows. In current study, the external diameter $(\mathrm{mm})$ of the brachial artery at proximal (left 6.63 and right 6.87 ), at middle (left 5.04 and right 5.24) and at distal (left 5.35 and right 5.54). The internal diameter $(\mathrm{mm})$ of brachial artery at proximal (left 6.14 and right 6.44), at middle (left 4.68 and right 4.90 ), and at distal (left 4.93 and right 5.09). The thickness of the brachial artery on the left side at proximal (0.25), at middle $(0.18)$, distal $(0.21)$.The thickness on the right side at proximal $(0.21)$ at middle $(0.17)$ at distal $(0.22)$. This figures shows the right side is significantly larger than the left. Therefore the artificial arteriovenous fistula is more suitable right than the left side. Furthermore, the proximal part is the accurate site for artificial fistula to connect the artery to vein based on internal and external diameter as well as wall thickness of the brachial artery. In previous study, the diameter of the brachial artery for men is $4.71 \pm 0.53$, women is $3.35 \pm 0.35 \mathrm{~mm}$ and in all subjects is $4.03 \pm 0.82 \mathrm{~mm}$ (JENSEN-URSTAD and ROSFORS, 1997). Our case is significantly larger because of connective tissue remain on the vessels or the number of population is greater than the report this may bring difference in result. In previous and current study, relatively the mean diameters of the female are significantly less than the male. This might be due to gender difference or the history of the individual at the time of death may influence the size of the artery.

\section{Conclusion}

It is important for surgeons to known the variable morphology and course of brachial artery to minimize surgical complication during operation. Clinician, surgeons and radiologist should be aware that the arterial diameter (both internal and external), wall thickness to improve the artificial arteriovenous fistula for patient who need haemodialysis.

Acknowledgements: We would like to thank all staffs working in Centre for Anatomy and Human Identification who prepare the required amenities for this research study as well as King Saud bin Abdulaziz University for Health Sciences.

\section{References}

AL-SOWAYIGH, MA., ZAKI, AI., EL-HAGGAGY, AA., ABDELAAL, $\mathrm{IH}$. and BADAWOUD, MH. Anatomical variation of brachial artery bifurcation. Saudi Medical Journal, 2013, vol. 34, n. 9, p. 908-912. PMid:24043001. 
BERGMAN, RA., THOMPSON, SA. and AFIFI, AK. Catalog of human anatomical variation. Baltimore: Urban Schwarzenberg, 1985.

CAVDAR, S., ZEYBEK, A. and BAYRAMICLI, M. Rare variation of the axillary artery. Clinical Anatomy (New York, N.Y.), 2000, vol. 13, n. 1, p. 66-68. http://dx.doi.org/10.1002/(SICI)10982353(2000)13:1<66::AID-CA8>3.0.CO;2-M. PMid:10617889.

CELIK, HH., GÖRMÜS, G., ALDUR, MM. and OZÇELIK, M. Origin of the radial and ulnar arteries: variation in 81 arteriograms. Morphologie, 2001, vol. 85, n. 269, p. 25-27. PMid:11534414.

CHERUKupalli, C., DWivedi, A. and DAYAL, R. High bifurcation of brachial artery with acute arterial insufficiency: a case report. Vascular and Endovascular Surgery, 2008, vol. 41, n. 6, p. 572-574. http://dx.doi.org/10.1177/1538574407305798. PMid:18166644.

CIERVO, A., KAHN, M., PANGILINAN, AJ. and DARDIK, H. Absence of the brachial artery: report of a rare human variation and review of upper extremity arterial anomalies. Journal of Vascular Surgery, 2001, vol. 33, n. 1, p. 191-194. http://dx.doi.org/10.1067/ mva.2001.112212. PMid:11137944.

DE GARIS, CF. and SWARTLEY, WB. The axillary artery in white and negro stocks. The American Journal of Anatomy, 1928, vol. 41, n. 2, p. 353-397. http://dx.doi.org/10.1002/aja.1000410208.

DURGUN, B., YÜCEL, A., KIZILKANAT, E. and DERE, F. Multiple arterial variation of the human upper limb. Surgical and Radiologic Anatomy, 2002, vol. 24, n. 2, p. 125-128. http://dx.doi. org/10.1007/s00276-002-0011-z. PMid:12197022.

GOSWAMI, P., TIGGA, SR. and BHARIHOKE, V. Variant course and branching of right brachial artery: a case study. International Journal of Research in Medical Sciences, 2013, vol. 1, n. 2, p. 62-65. http://dx.doi.org/10.5455/2320-6012.ijrms20130504.

JENSEN-URSTAD, K. and ROSFORS, S. A methodological study of arterial wall function using ultrasound technique. Clinical Physiology (Oxford, England), 1997, vol. 17, n. 6, p. 557-567. http://dx.doi. org/10.1046/j.1365-2281.1997.00063.x. PMid:9413643.

JURJUS, AR., CORREA-DE-ARUAUJO, R. and BOHN, RC. Bilateral double axillary artery: embryological basis and clinical implications. Clinical Anatomy (New York, N.Y.), 1999, vol. 12 , n. 2 , p. 135-140. http://dx.doi.org/10.1002/(SICI)10982353(1999)12:2<135::AID-CA10>3.0.CO;2-M. PMid:10089041.

KIAN, K., SHAPIRO, JA., SALMAN, L., KHAN, RAH., MERRILL, D., GARCIA, L., EID, N., ASIF, A., ALDAHAN, A. and BEATHARD, G. High brachial artery bifurcation: clinical considerations and practical implications for an arteriovenous access. Seminars in Dialysis, 2012, vol. 25 , n. 2, p. 244-247. http://dx.doi.org/10.1111/j.1525139X.2011.00964.x. PMid:21929569.

KIRKSEY, L. Unrecognized high brachial artery bifurcation is associated with higher rate of dialysis access failure. Seminars in Dialysis, 2012, vol. 24, n. 6, p. 698-702. PMid:21929569.

LAPPAS, DA., LIASKOVITIS, B. and GISAKIS I. The brachial artery and the superficial brachial artery. The Journal of Bone \& Joint Surgery, 2004, vol. 86B, supplement 2, p. 164.

LIOUPIS, C., Mistry, H., JUNGHANS, C., HAUGHEY, N., FREEDMAN, B., TYRRELL, M. and VALENTI, D. High brachial artery bifurcation is associated with failure of brachiocephalic autologous arteriovenous fistulae. The Journal of Vascular Access, 2010, vol. 11, n. 2, p. 132-137. PMid:20155716.

MALCIC-GÜRBÜZ, J., GURUNLUOGL, R., OZDOGMUS, O. and YALIN, A. Unique case of trifurcation of the brachial artery: its clinical significance. Clinical Anatomy (New York, N.Y.), 2002, vol. 15 , n. 3, p. 224-227. http://dx.doi.org/10.1002/ca.10005. PMid:11948959.

MCCORMACK, LJ., CAULDWELL, EW. and ANSON, BJ. Brachial and antebrachial arterial patterns; a study of 750 extremities. Surgery, Gynecology \& Obstetrics, 1953, vol. 96, n. 1, p. 43-54. PMid:13015348.

MOORE, KL. and PERSAUD, TVN. The limbs developing human: clinically oriented embryology. 6th ed. India: Harcourt Asia, 1999. p. $442-444$.

NAKATANI, T., TANAKA, S., MIZUKAMI, S., SHIRAISHI, Y. and NAKAMURA, T. The superficial ulnar artery originating from the axillary artery. Annals of Anatomy, 1996, vol. 178, n. 3, p. 277-279. http://dx.doi.org/10.1016/S0940-9602(96)80068-9. PMid:8712378.

PANDEY, SK., GANGOPADHYAY, AN., TRIPATHI, SK. and SHUKLA, VK. Anatomical variations in termination of the axillary artery and its clinical implications. Medicine, Science, and the Law, 2004, vol. 44, n. 1, p. 61-66. http://dx.doi.org/10.1258/ rsmmsl.44.1.61. PMid:14984216.

PATNAIK, VVG., KALSEY, G. and SINGLA, RK. Trifurcation of brachial artery: a case report. Journal of the Anatomical Society of India, 2001, vol. 50, n. 2, p. 163-165.

QUAIN, R. The anatomy of the arteries of the human body, and its applications to pathology and operative surgery. London: Taylor and Walter, 1844. p. 235-271.

QUARRAT, UL., KAUSER, Y. and RAZA, TA. High division of brachial artery and analogus? Start of radial and ulnar arteries. Annals of King Edward Medical College, 2002, vol. 8, n. 1, p. 30-31.

RODRIGUEZ-BAEZA, A., NEBOT, J., FERREIRA, B., REINA, F., PEREZ, J., SANUDO, JR. and ROIG, M. An anatomical study and ontogenic explanation of 23 cases with variations in the main pattern of the human brachio-antebrachial arteries. Journal of Anatomy, 1995, vol. 187, n. Pt 2, p. 473-479. PMid:7592009.

RODRIGUEZ-NIEDENFUHR, M., VAZQUEZ, T., NEARN, L., FERREIRA, B., PARKIN, I. and SANUDO, JR. Variations of the arterial pattern in the upper limb revisited: a morphological and statistical study, with a review of the literature. Journal of Anatomy, 2001, vol. 199, n. Pt 5, p. 547-566. http://dx.doi. org/10.1046/j.1469-7580.2001.19950547.x. PMid:11760886.

SATHYNARAYAN, N., SUNITHA, P., SHAIK, MM. and DEVI, PSV. Brachaial artery with high up division with its embryology basis and clinical significance. International Journal of Anatomical Variations, 2010, vol. 3, p. 56-58.

SINGER, E. Embryological patterns persisting in the arteries of the arm. The Anatomical Record, 1933, vol. 55, n. 4, p. 406-413. http://dx.doi.org/10.1002/ar.1090550407.

SINGH, H., GUPTA, N., BARGOTRA, R.N. and SINGH, NP. Higher bifurcation of brachial artery with superficial course of radial artery in forearm. JK Science, 2010, vol. 12, n. 1. p. 39-40.

STANDRING, S. Gray's anatomy: the anatomical basis of clinical practice. 39th ed. London: Churchill Livingstone, 2004.

VALLOLA, VR., NAGABHOOSHANA, S. and BHAT, SM. Trifurcation of brachial artery with variant coarse of radial artery: rare variation. Anatomical Science International, 2008, vol. 83, n. 4, p. 307-309. http://dx.doi.org/10.1111/j.1447-073X.2008.00235.x. PMid:19159366. 
AL TALALWAH, W., GETACHEW, D. and SOAMES, R.

VANDANA, R., SURESH, NM., PRABHA, LR. and PAI, V. Variation in course and branching pattern of Brachial artery. Anatomica Karnataka, 2012, vol. 6, n. 3, p. 42-48.

WATANABE, M., TAKATSUJI, K., SAKAMOTO, N., MORITA, Y. and ITO, H. Two cases of fusion of the musculocutaneous and median nerves. Kaibogaku Zasshi, 1985, vol. 60, n. 1, p. 1-7. PMid:3832747.

YOSHINAGA, K., TANII, I. and KODAMA, K. Superficial brachial artery crossing over the ulnar and median nerves from posterior to anterior: embryological significance. Anatomical Science International, 2003, vol. 78, n. 3, p. 177-180. http://dx.doi.org/10.1046/j.00227722.2003.00053.x. PMid:14527132.

Received August 5, 2014 Accepted November 17, 2015 